\title{
EFIKASI ASAP CAIR DARI TANDAN KOSONG KELAPA SAWIT (TKKS) DALAM PENEKANAN PERKEMBANGAN JAMUR ASPERGILLUS NIGER
}

\author{
Hasan Ashari Oramahi ${ }^{1}$, Farah Diba ${ }^{1} \&$ Wahdina $^{1}$
}

\begin{abstract}
The efficacy of liquid smoke from oilpalm empty fruit bunch in suppressing the development of fungus. Fungi that have been grown on maize seed were Aspergillus niger, A. flavus and Aspergillus sp. From those species, A. niger is important species because of its toxigenic characteristic on agricultural product. The objective of this research was to evaluate the efficacy of oilpalm empty fruit bunch liquid smoke in suppressing the development of the fungus. This research was conducted in several steps i.e. pyrolisis of liquid smoke, analysis of liquid smoke content, and efficacy test of liquid smoke as antifungal. Agar media used was PDA (potato dextrose agar) and concentration of liquid smoke was $0,1,2$, and 3\% (v/v). The results indicated that the liquid smoke inhibited the fungal growth. The highest result was on liquid smoke with temperature pyrolisis of 400 and $450^{\circ} \mathrm{C}$ and concentration $3 \%$ with average value of $100 \%$. The contents of organic fraction of liquid smoke, such as acid and phenol might be responsible for the difference in antifungal activities among this liquid smoke.
\end{abstract}

Key words: efficacy, Aspergillus niger, liquid smoke, oilpalm empty fruit bunch, antifungal

\section{PENDAHULUAN}

Salah satu penyebab kehilangan pascapanen jagung adalah karena serangan jamur. Beberapa jamur yang menyerang biji jagung antara lain Aspergillus flavus, A. niger dan Mucor sp. (Muis et al., 2002; Oramahi et al., 2009). Di antara jamur tersebut, A. niger merupakan jamur yang penting karena selain menimbulkan kerusakan bahan yang disimpan (Sekiyama et al., 2005; Essono et al., 2007), juga menyebabkan kehilangan hasil yang cukup besar (Oramahi et al., 2006; Oramahi, 2008).

Penggunaan fungisida sintetik yang mengandung zat-zat kimia sulit terdegradasi sehingga berpotensi dapat menyebabkan pencemaran lingkungan. Untuk mengurangi penggunaan fungisida sintetik dapat dilakukan dengan menggunakan fungisida yang ramah lingkungan, tetapi tetap dapat digunakan untuk mengatasi kerusakan yang disebabkan oleh jamur. Hal ini dapat dilakukan dengan menggunakan bahan-bahan alami yang berasal dari tumbuh-tumbuhan.

Penggunaan bahan-bahan alami sebagai bahan pengawet alternatif yang lebih aman bagi lingkungan (biodegradable) dan bersifat dapat diperbaharui (renewable) merupakan teknologi alternatif yang perlu dikembangkan. Salah satu bahan alami yang dapat digunakan adalah penggunaan asap cair. Asap cair merupakan suatu campuran larutan dari dispersi koloid asap kayu dalam air, yang dibuat dengan mengkondensasikan asap dari hasil pembakaran kayu tersebut. Kayu sebagai komponen bahan bakar umumnya tersusun atas selulosa, hemiselulosa dan lignin sedangkan komponen lainnya terdiri dari tanin, resin dan terpentin (Fengel \& Wegener, 1995).

Di Indonesia bahan baku untuk pembuatan asap cair sangat banyak tersedia. Salah satunya limbah pengolahan tandan buah segar kelapa sawit. Dalam proses produksi minyak sawit, tandan kosong kelapa sawit (TKKS) merupakan limbah terbesar yaitu sekitar 23\% tandan buah segar (TBS) (Widiastuti \& Panji, 2007). Oleh karena itu, potensi TKKS cukup besar untuk bahan baku pembuatan asap cair. Penelitian sebelumnya menunjukkan bahwa asap cair mengandung komponen yang berfungsi sebagai antimikrobia (antijamur). Inoue et al. (2000) meyatakan bahwa asap cair mampu menghambat pertumbuhan Fomitopsis palustris dan Trametes versicolor. Penelitian terakhir menunjukkan bahwa asap cair mampu menghambat pertumbuhan jamur Ophiostoma polonicum, O. flexuosum, O. narcissi dan O. tetropii (Velmurugan et al., 2009a; Velmurugan et al., 2009b).

\footnotetext{
${ }^{1}$ Fakultas Kehutanan, Universitas Tanjungpura, Jl. Imam Bonjol Pontianak. E-mail: oramahi_stp@yahoo.com
} 
Berdasarkan pertimbangan di atas, perlu dilakukan penelitian efikasi asap cair dari TKKS untuk penghambatan pertumbuhan A. niger secara in vitro. Penelitian bertujuan untuk mengetahui aktivitas antijamur. Aktivitas antijamur dinyatakan dengan indeks antijamur.

\section{METODE PENELITIAN}

Persiapan bahan baku TKKS dilakukan di Laboratorium Wood Workshop, pengujian asap cair terhadap jamur dilakukan di Laboratorium Teknologi Kayu, Fakultas Kehutanan, Universitas Tanjungpura. Pirolisis asap cair TKKS dilakukan di Laboratorium Rekayasa, Fakultas Teknologi Pertanian, UGM, analisis kadar fenol dan asam dilakukan di Laboratorium Kimia dan Biokimia, Fakultas Teknologi Pertanian, UGM. Penelitian dilakukan pada bulan Juli sampai Oktober 2009.

Koleksi Isolat. Isolat $A$. niger diperoleh dari hasil penelitian sebelumnya (Oramahi et al., 2009). Isolat ditumbuhkan pada media potato dextrose agar miring (PDA) dan diinkubasi selama 7 hari pada suhu ruang.

Pembuatan asap cair (Tranggono et al., 1996; Darmadji et al., 2000). Asap cair dibuat dengan memasukkan serbuk TKKS ke dalam reaktor kemudian ditutup dan rangkaian kondensor dipasang. Selanjutnya dapur pemanas dihidupkan dengan suhu yang dikehendaki. Pada penelitian ini suhu yang digunakan adalah 350,400 , dan $450^{\circ} \mathrm{C}$. Waktu pirolisis yang digunakan adalah 90 menit. Asap yang keluar dari reaktor disalurkan ke kolom pendingin melalui pipa penyalur, kemudian ke dalam kolom pendingin ini dialirkan air dingin dengan menggunakan pompa. Embunan berupa asap cair ditampung dalam botol, sedangkan asap yang tidak dapat diembunkan dibuang melalui pipa penyalur asap sisa. Rendemen asap cair termasuk di dalamnya tar dan arang yang diperoleh dihitung sebagai $\%$ berat.

\section{Identifikasi Komponen Asap Cair dengan GC-MS (Gas Chromathography-Mass Spectrocopy). Analisa} senyawa-senyawa penyusun asap cair secara kualitatif dengan menggunakan GC-MS yaitu: asap cair diekstrak dengan menggunakan pelarut diklorometan, ke dalam 5 $\mathrm{ml}$ asap cair ditambahkan $5 \mathrm{ml}$ diklorometan kemudian digojog dalam corong pemisah selama 5 menit. Setelah didiamkan sebentar fraksi atas (diklorometan) dipisahkan dari fraksi bawah. Kemudian fraksi atas ditampung dan ke dalam fraksi bawah ditambahkan lagi $5 \mathrm{ml}$ diklorometan, digojog lagi dalam corong pemisah seperti yang pertama tadi. Fraksi atas yang dihasilkan ekstraksi kedua ini dicampurkan dengan fraksi atas hasil pemisah pertama, kemudian dipekatkan dengan meniupkan gas Nitrogen sampai volume yang terisi $1 \mathrm{ml}$. Hasil tersebut kemudian dideteksi menggunakan GC-MS dengan kondisi operasi: jenis pengion: EI (Electron Impact), suhu injektor: $280^{\circ} \mathrm{C}$, jenis kolom: DB-1 (Fussed silica) dengan panjang $30 \mathrm{~m}$, suhu kolom $70^{\circ} \mathrm{C}$ dengan kenaikan $5^{\circ} \mathrm{C}$ menit ${ }^{-1}$, gas pembawa: Helium dengan tekanan 10 K.Pa.

Analisis Fenol (Senter et al., 1989). Satu ml asap cair ditimbang dan diencerkan sampai volume $1000 \mathrm{ml}$. Dari larutan ini diambil $1 \mathrm{ml}$ dan ditambahkan dengan 5 ml larutan $\mathrm{NaCO}_{3}$ alkalis dan dibiarkan pada suhu kamar selama 10 menit. Kemudian ditambahkan 0,5 ml reagen Folin-Ciocalteau (reagen komersial : aquades 1:1 v/v) dan digojok dengan vortex-shaker. Setelah dibiarkan selama 30 menit absorbansinya dibaca terhadap larutan blanko pada panjang gelombang $750 \mathrm{~mm}$. Konsentrasi fenolat larutan sampel dihitung berdasarkan kurva standar yang diperoleh dari larutan fenol murni.

Analisis Asam (AOAC, 1990). Asap cair ditimbang lebih kurang $1 \mathrm{ml}$, lalu diencerkan sampai volume 100 ml. Selanjutnya dititrasi dengan larutan standar $\mathrm{NaOH}$ $0,1 \mathrm{~N}$ sampai pHnya 8 . Kadar asam dinyatakan dalam persen berat asam asetat.

Efikasi Asap Cair dari TKKS Sebagai Antijamur. Efikasi asap cair sebagai antijamur TKKS dilakukan dengan menggunakan peracunan makanan. Prosedur pengujian antijamur asap cair dilakukan secara in vitro dengan mengacu pada Loman (1970 dalam Yoshimoto \& Syafii, 1993) yang dimodifikasi. Cawan Petri yang sudah disterilkan diisi dengan media PDA masing-masing $10 \mathrm{ml}$, kemudian dicampur dengan asap cair sesuai dengan konsentrasi yang telah ditentukan sebagai berikut: $0,1,2$, dan 3\%. Kemudian biakan murni dari jamur Aspergillus niger diinokulasi dibagian tengah cawan Petri dan diinkubasi pada suhu kamar. Pengamatan dilakukan terhadap pertumbuhan koloni jamur dengan mengukur diameter koloni pada hari ke 2, 3, 4, 5, 6 dan 7 setelah inokulasi. 
Aktivitas antijamur dinyatakan dengan indeks antijamur (Zhong et al., 2007 cit. Velmurugan et al., 2009a) dengan persamaan sebagai berikut:

Indeks anti jamur $=\left(1-\frac{\mathrm{Dt}}{\mathrm{Dc}}\right) \times 100 \%$

dimana:

$\mathrm{Dt}=$ diameter koloni jamur perlakuan $(\mathrm{cm})$

$\mathrm{Dc}=$ diameter koloni jamur kontrol $(\mathrm{cm})$

\section{Rancangan Penelitian}

Rancangan yang digunakan pengaruh suhu dan konsentrasi asap cair terhadap indeks antijamur adalah rancangan acak lengkap dengan pola faktorial. Faktor I adalah konsentrasi asap cair terdiri atas $0,1,2$, dan $3 \%$. Faktor II adalah suhu pirolisis asap cair terdiri atas 350, 400 , dan $450^{\circ} \mathrm{C}$. Data kadar asam dan fenol yang diperoleh dianalisis dengan sidik ragam (analysis of variance). Untuk mengungkapkan pengaruh antarperlakuan digunakan uji BNT pada taraf nyata $5 \%$.

\section{HASIL DAN PEMBAHASAN}

Hasil Identifikasi Komponen Asap Cair. Hasil identifikasi asap cair TKKS pada suhu pirolisis $350^{\circ} \mathrm{C}$ dengan GC MS menunjukkan bahwa terdapat 21 (puncak) atau 21 jenis senyawa penyusun asap cair (Gambar 1). Dari 21 puncak tersebut diambil 4 puncak yang dominan. Adapun 4 puncak yang dominan tersebut, terlihat pada Tabel 1.

Hasil identifikasi asap cair TKKS pada suhu pirolisis $400^{\circ} \mathrm{C}$ dengan GC MS menunjukkan bahwa terdapat 14 (puncak) atau 14 jenis senyawa penyusun asap cair (Gambar 2). Dari 14 puncak tersebut diambil 4 puncak yang dominan. Adapun 4 puncak yang dominan tersebut, terlihat pada Tabel 2.

Hasil identifikasi asap cair TKKS pada suhu pirolisis $450^{\circ} \mathrm{C}$ dengan GC MS menunjukkan bahwa terdapat 17 (puncak) atau 17 jenis senyawa penyusun asap cair (Gambar 3). Dari 17 puncak tersebut diambil 4 puncak yang dominan. Adapun 4 puncak yang dominan tersebut, terlihat pada Tabel 3.

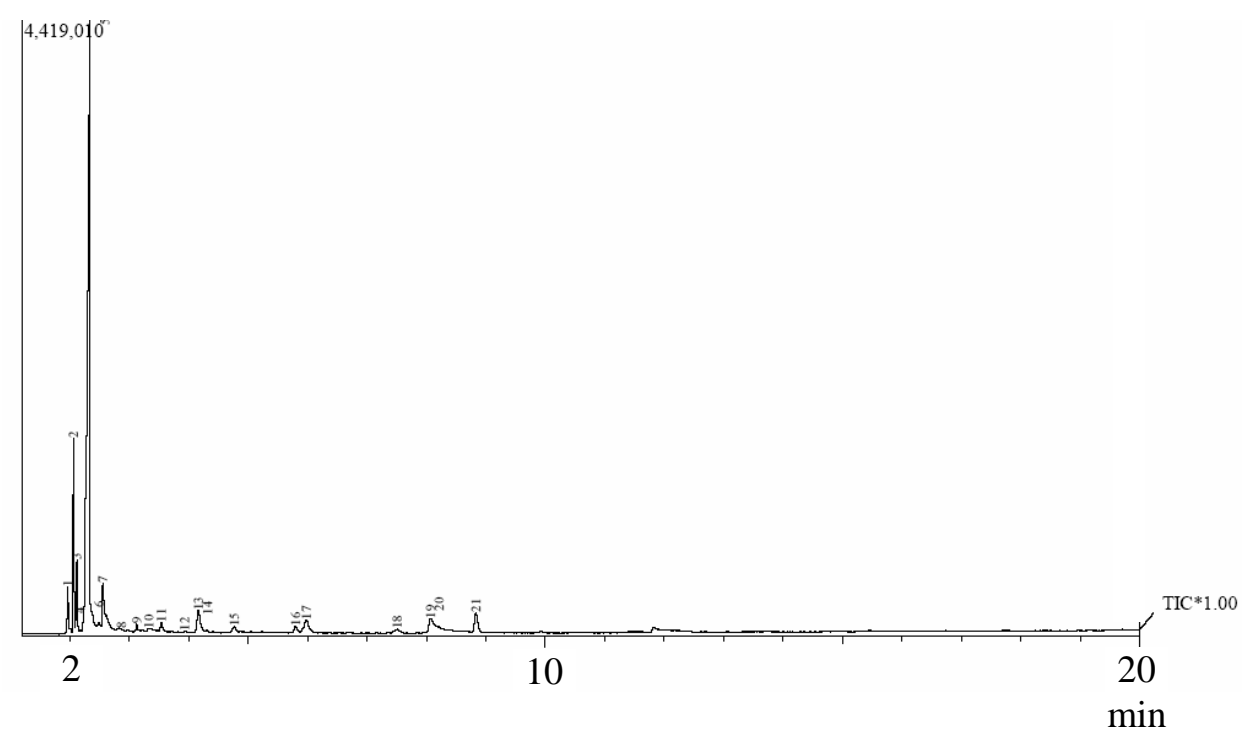

Gambar 1. Spektra GC MS asap cair TKKS pada suhu pirolisis $350^{\circ} \mathrm{C}$

Tabel 1. Komponen kimia dan waktu retensi asap cair TKKS pada suhu pirolisis $350^{\circ} \mathrm{C}$

\begin{tabular}{cccrc}
\hline Peak No. & $\begin{array}{c}\text { Retention Time } \\
\text { (minute) }\end{array}$ & $\begin{array}{c}\text { Area } \\
(\%)\end{array}$ & Height & Chemical Compound \\
\hline 1 & 1,965 & 2,70 & 333396 & Formic acid \\
2 & 2,061 & 8,45 & 1396934 & n-Butane \\
3 & 2,114 & 3,54 & 521460 & Ethanoic acid \\
5 & 2,333 & 61,64 & 4391079 & Acetic acid \\
\hline
\end{tabular}




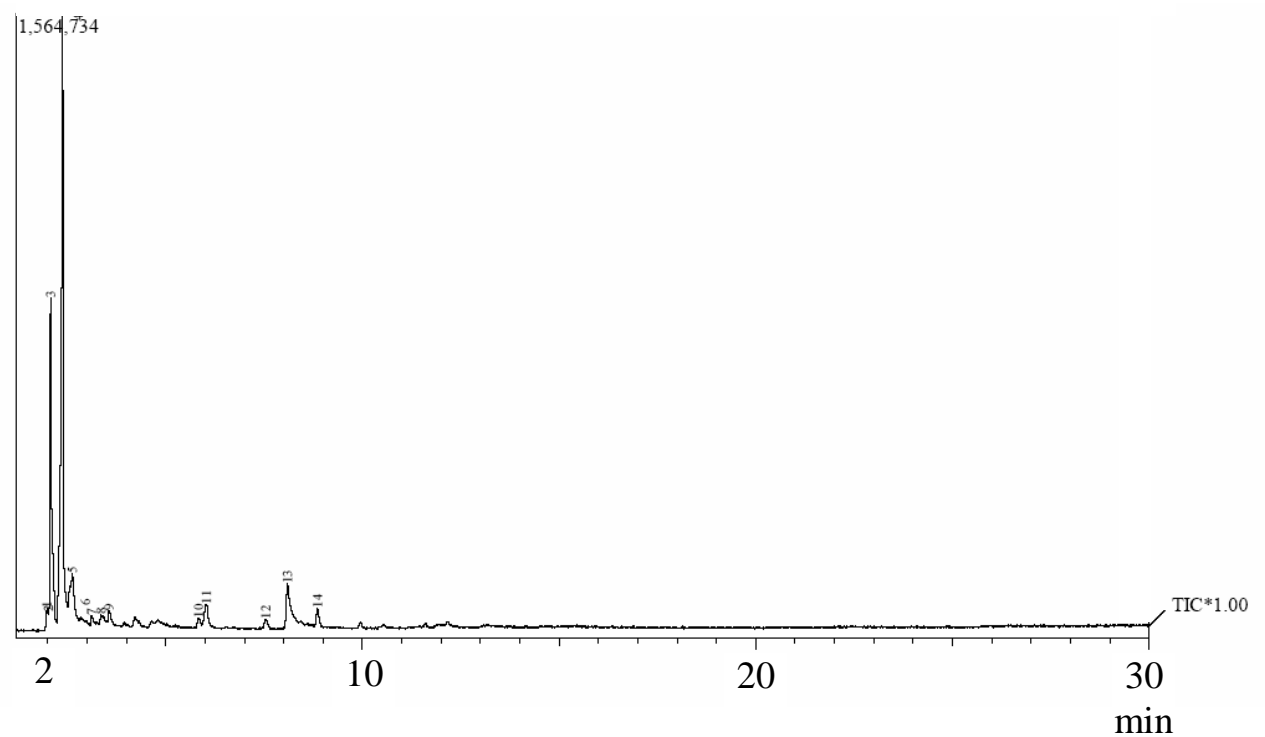

Gambar 2. Spektra GC MS asap cair TKKS pada suhu pirolisis $400^{\circ} \mathrm{C}$

Tabel 2. Komponen kimia dan waktu retensi asap cair TKKS pada suhu pirolisis $400^{\circ} \mathrm{C}$

\begin{tabular}{ccccc}
\hline Peak No. & $\begin{array}{c}\text { Retention Time } \\
\text { (minute) }\end{array}$ & $\begin{array}{c}\text { Area } \\
(\%)\end{array}$ & Height & Chemical Compound \\
\hline 3 & 2,067 & 22,95 & 2545622 & 2-Propanone \\
4 & 2,381 & 50,17 & 5564496 & Acetic acid \\
5 & 2,626 & 8,64 & 958612 & Acetylcarbinol \\
13 & 8,094 & 5,51 & 611163 & Phenol \\
\hline
\end{tabular}

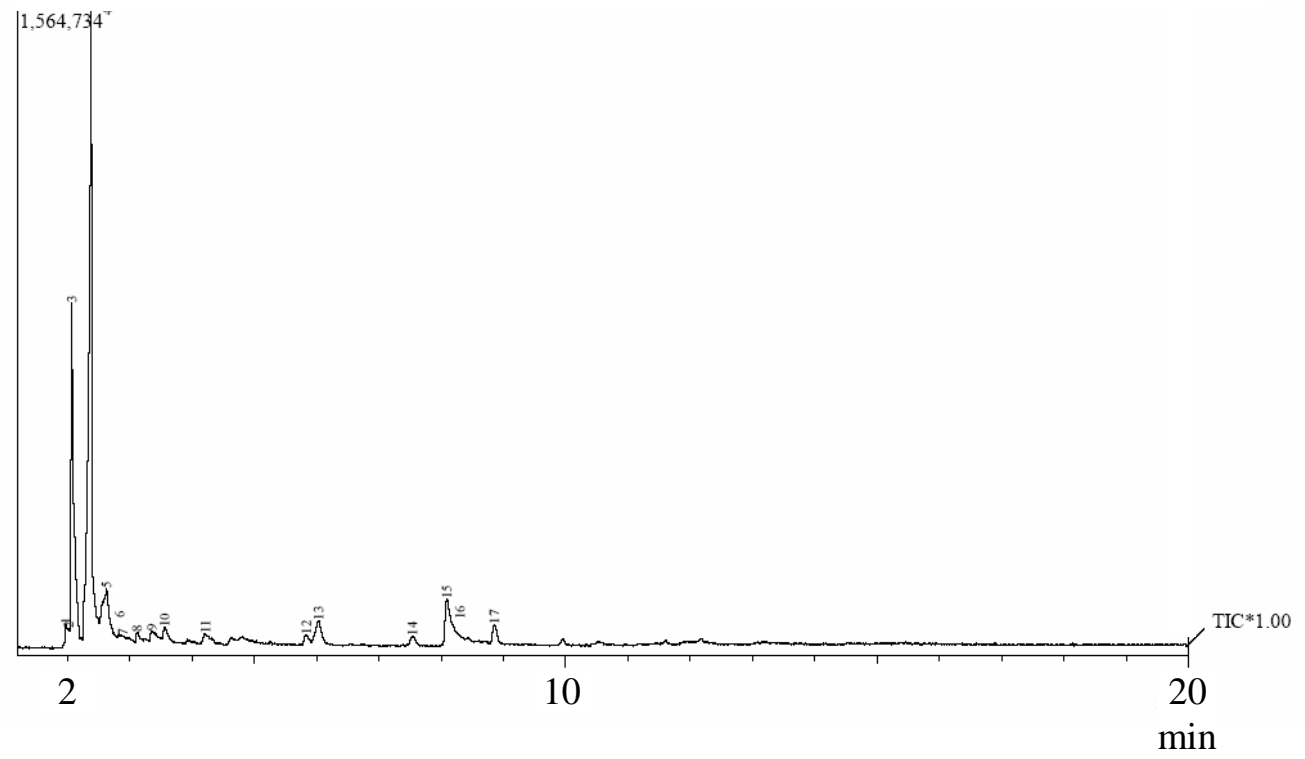

Gambar 3. Spektra GC MS asap cair TKKS pada suhu pirolisis $450^{\circ} \mathrm{C}$ 
Hasil identifikasi asap cair TKKS pada suhu yang berbeda (Tabel 1, 2, dan 3) menunjukkan perbedaan jumlah komponen penyusun secara keseluruhan. Namun komponen penyusun asap cair yang dominan hampir sama yaitu terdiri atas komponen asam dan fenol. Hal ini menunjukkan bahwa suhu pirolisis berpengaruh terhadap komponen asap cair. Lin et al. (2008) meneliti asap cair dari bambu Moso (Phyllostachys heterocycla Milf) dengan suhu pirolisis yang berbeda. Hasil penelitian menyatakan suhu yang berbeda menghasilkan komposisi asap cair bambu yang berbeda, dan komponen yang dominan pada asap cair bambu Moso sama dengan penelitian ini, yaitu komponen asam dan fenol. Suhu yang digunakan Lin et al. (2008) sebesar $80-150^{\circ} \mathrm{C}$ dan menghasilkan asap cair dengan kandungan asam organik yang bervariasi sebesar 3,52-7,21\%. Suhu pirolisis mempengaruhi proses terbentuknya asam organik pada asap cair. Oleh karena itu perlu dilakukan analisis lebih lanjut terhadap komponen asam dan fenol secara kuantitatif.

\section{Komponen Kimiawi Asap Cair}

Hasil analisis komponen asam dan fenol dari asap cair dari TKKS terlihat pada Tabel 4. Tabel 4 menunjukkan bahwa makin tinggi suhu pirolisis makin tinggi kadar asam. Hal ini menunjukkan bahwa suhu pirolisis memberikan pengaruh nyata terhadap kadar asam dalam asap cair. Hasil penelitian Lin et al. (2008) menyatakan makin tinggi suhu pirolisis, makin meningkat kandungan asam pada asap cair bambu Moso. Kadar asam dalam asap cair TKKS sebesar 5,41-6,31\%. Asam yang terdapat dalam asap cair TKKS meliputi asam format, asam etanoat, asam asetat, dan asam karbonil. Hal ini diperkuat dengan hasil penelitian Maga (1987) dan Girard (1992) yang menyatakan kandungan kimia asap cair dipengaruhi oleh berbagai faktor, antara lain suhu pirolisis, jenis kayu, dan kadar air kayu,

Makin tinggi suhu pirolisis makin tinggi kadar fenol. Hal ini menunjukkan bahwa suhu pirolisis mempengaruhi kadar fenol. Hal ini sesuai dengan penelitian Inoue et al. (2000) yang menyatakan bahwa guaicol dan 4-methyl guaicol meningkat dengan bertambahnya suhu pirolisis. Senyawa guaiacol dan 4methyl guaiacol termasuk kelompok fenol. Girard (1992) menyatakan bahwa baik kuantitas maupun kualitas senyawa fenol yang terdapat pada asap cair langsung berhubungan dengan suhu pirolisis kayu.

\section{Pengujian Aktivitas Antijamur}

Pengaruh suhu pirolisis dan konsentrasi asap cair TKKS terhadap indeks antijamur terlihat pada Tabel 5. Hasil analisis sidik ragam menunjukkan bahwa suhu pirolisis, konsentrasi asap cair serta interaksi keduanya berpengaruh nyata. Tabel 5 menunjukkan bahwa makin tinggi suhu dan konsentrasi asap cair makin tinggi indeks antijamur. Hal ini diperkuat dengan hasil analisis kadar

Tabel 3. Komponen kimia dan waktu retensi asap cair TKKS pada suhu pirolisis $450^{\circ} \mathrm{C}$

\begin{tabular}{cclcc}
\hline Peak No. & $\begin{array}{c}\text { Retention Time } \\
\text { (minute) }\end{array}$ & $\begin{array}{c}\text { Area } \\
(\%)\end{array}$ & Height & Chemical Compound \\
\hline 3 & 2,059 & 19,16 & 1767218 & Butane \\
4 & 2,112 & 2,96 & 181121 & Furanone \\
6 & 2,314 & 47,07 & 1583189 & Ethanoic acid \\
17 & 8,061 & 5,48 & 92614 & Phenol \\
\hline
\end{tabular}

Tabel 4. Komponen asam dan fenol asap cair TKKS hasil pirolisis pada suhu yang berbeda

\begin{tabular}{ccc}
\hline Suhu $\left({ }^{\circ} \mathrm{C}\right)$ & Kadar Asam $(\%)$ & Kadar Fenol (\%) \\
\hline 350 & $5,41 \mathrm{a}$ & $2,18 \mathrm{a}$ \\
400 & $5,89 \mathrm{~b}$ & $2,26 \mathrm{~b}$ \\
450 & $6,31 \mathrm{c}$ & $3,63 \mathrm{c}$ \\
\hline
\end{tabular}

Keterangan : Rerata yang diikuti oleh huruf yang sama pada kolom yang sama berarti tidak berbeda nyata $(\mathrm{P}>0,05)$. 
asam dan fenol (Tabel 4). Perlakuan suhu 400 dan $450^{\circ} \mathrm{C}$ dengan konsentrasi asap cair 3\% mempunyai indeks antijamur tertinggi $(100 \%)$. Suhu pirolisis tinggi menghasilkan kadar asam dan fenol yang semakin tinggi. Kimura et al. (2002) menyatakan asam dan fenol yang terdapat di dalam asap cair berperan sebagai bahan antijamur.

Hasil penelitian menunjukkan bahwa diperlukan konsentrasi yang tinggi untuk menekan pertumbuhan A. niger. Pada konsentrasi yang tinggi berarti kandungan bahan aktif di dalam asap cair juga tinggi sehingga lebih banyak bahan aktif yang dapat mengganggu metabolisme di dalam jamur. Shiah et al. (2006) menyatakan pertumbuhan jamur semakin terhambat dengan semakin tinggi konsentrasi asap cair dari bambu yang terdapat pada media jamur. Hal ini disebabkan tingginya absorpsi asam dan fenol dari asap cair pada media jamur. Asam dan fenol mengganggu membran sel jamur sehingga menyebabkan permeabilitas membran sel meningkat dan akhirnya jamur kehilangan isi sel.

Inoue et al. (2000) menyatakan bahwa asap cair mempunyai kemampuan menghambat pertumbuhan jamur. Makin tinggi suhu pirolisis asap cair makin tinggi daya penghambatannya terhadap pertumbuhan Fomitopsis palustris dan Trametes versicolor. Menurut Velmurugan et al. (2009a), asap cair dari serbuk gergaji kayu Pinus densiflora dan Quercus serrata yang telah dinetralkan mempunyai kemampuan sebagai antijamur. Lebih lanjut dinyatakan bahwa konsentrasi asap cair sebesar $2 \%$ mempunyai kemampuan yang kuat dalam menghambat pertumbuhan jamur Ophiostoma polonicum, $O$. flexuosum, $O$. narcissi dan $O$. tetropii. Lin et al. (2008) melaporkan bahwa asap cair dari bambu Moso hasil pirolisis pada suhu $80-150^{\circ} \mathrm{C}$ mampu menghambat pertumbuhan jamur Trichoderma viride dengan efisiensi penghambatan sebesar 50-150\%.

Hasil analisis komponen penyusun asap cair khususnya kadar asam dan fenol (Tabel 4) menunjukkan bahwa komponen tersebut yang berperan sebagai antijamur. Hal ini diperkuat hasil penelitian yang dilakukan oleh Velmurugan et al. (2009b) yang menyatakan bahwa komponen 2,6 dimethoxy phenol, dehydroacetic acid dan 2,3,5 trimethoxytoluene dalam asap cair serbuk gergaji dan bambu mampu berperan sebagai antijamur. Velmurugan et al. (2009a) menyatakan bahwa terdapat tujuh komponen dalam asap cair hasil pirolisis dari serbuk Pinus densiflora dan Quercus serrata yaitu 2,6 dimethoxy Phenol, Phenol (Izal), 2-methyl phenol (ocresol), 4-methyl phenol (p-cresol), 2-methoxy phenol (guaiacol), 2-methoxy-4 methyl phenol dan 4-ethyl2-methoxy phenol yang mampu berperan sebagai antijamur. Komponen-komponen penyusun asap cair di atas merupakan kelompok fenol.

Mekanisme aktivitas senyawa antimikrobia fenol meliputi reaksi dengan membran sel yang menyebabkan meningkatnya permeabilitas membran sel dan

Tabel 5. Pengaruh suhu pirolisis dan konsentrasi asap cair terhadap indeks antijamur

\begin{tabular}{cccc}
\hline \multicolumn{2}{c}{ Perlakuan } & \multicolumn{2}{c}{ Indeks Antijamur } \\
\hline Suhu $\left({ }^{\circ} \mathrm{C}\right)$ & Konsentrasi $(\%)$ & Data asli $(\%)$ & Hasil transformasi $^{1)}$ \\
\hline 350 & 0 & $0 \mathrm{a}$ & 2,78 \\
400 & 0 & $0 \mathrm{a}$ & 2,78 \\
450 & 0 & $0 \mathrm{a}$ & 2,78 \\
350 & 1 & $0 \mathrm{a}$ & 2,78 \\
400 & 1 & $0 \mathrm{a}$ & 2,78 \\
450 & 1 & $0 \mathrm{a}$ & 2,78 \\
350 & 2 & $37,03 \mathrm{bc}$ & 37,44 \\
400 & 2 & $29,63 \mathrm{~b}$ & 32,18 \\
450 & 2 & $40,74 \mathrm{c}$ & 39,62 \\
350 & 3 & $62,97 \mathrm{~d}$ & 52,88 \\
400 & 3 & $100 \mathrm{e}$ & 89,04 \\
450 & 3 & $100 \mathrm{e}$ & 89,04 \\
\hline
\end{tabular}

1) Data ditransformasi dengan arcsin.

2) Rerata yang diikuti oleh huruf yang sama dalam kolom yang sama berarti tidak berbeda nyata $(\mathrm{P}>0,05 \%)$. 
mengakibatkan hilangnya isi sel, inaktivasi enzim-enzim esensial dan perusakan atau inaktivasi fungsional materi genetik (Davidson \& Branen, 1993 cit. Karseno et al., 2001). Selain kandungan fenol yang berperan sebagai antijamur, asam juga mempunyai peran yang sama sebagai bahan antijamur. Asam yang terdapat dalam asap cair TKKS meliputi asam format, asam etanoat, asam asetat, dan asam karbonil. Sifat antimikrobia asam asetat dalam asap cair TKKS terkait dengan kondisi $\mathrm{pH}$. Semakin tinggi $\mathrm{pH}$ menyebabkan kemampuan asam asetat dalam menghambat pertumbuhan jamur berkurang. Hal ini disebabkan karena asam asetat pada kondisi pH tinggi (6-7) tidak mampu terdisosiasi sehingga lebih cepat berpenetrasi ke dalam membrane sel jamur. Sedangkan asam format dan asam propionat mampu menghambat mikrobia dengan cara memblok sistem metabolisme sel melalui penghambatan terhadap aktivitas enzim (Luck \& Jager, 1997 cit. Karseno et al., 2001).

\section{SIMPULAN}

Berdasarkan hasil penelitian dapat ditarik beberapa kesimpulan, yaitu (1) asap cair dari TKKS dapat berperan sebagai antijamur, (2) konsentrasi asap cair sebesar $3 \%$ pada suhu $400^{\circ} \mathrm{C}$ dan $450^{\circ} \mathrm{C}$ mempunyai indeks antijamur tertinggi (100\%), dan (3) makin tinggi suhu pirolisis dan konsentrasi asap cair makin tinggi indeks antijamur.

\section{DAFTAR PUSTAKA}

AOAC. 1990. Association of Analytical Chemist, Official Method of Analysis. $18^{\text {th }}$ edition. Benyamin Franklin. Washington DC.

Darmadji P, Oramahi HA, Haryadi \& Armunanto R. 2000. Optimasi Produksi dan Sifat Fungsional Asap Cair Kayu Karet. Agritech 20(3): 147-155.

Essono G, Ayodele M, Akoa A, Foko J, Olembo S \& Gockowski J. 2007. Aspergillus species on Cassava Chips in Storage in Rural Areas of Southern Cameroon: Their Relationship with Storage Duration, Moisture Content and Processing Methods. Afr J. Microbiol Res. Online http//www/ academicjournals.org/ajmr. Diakses tanggal 7 Agustus 2009.
Fengel D \& Wagener G. 1995. Kayu: Kimia, Ultra Struktur, Reaksi-reaksi. Hardono Sastrohamidjojo (Penerjemah). Gadjah Mada University Press. Yogyakarta.

Girard JP. 1992. Technology of Meat and Meat Product Smoking. Ellis Harwood. New York, London, Toronto, Sydney, Tokyo, Singapore: 162201.

Inoue S, Hata T, Imamura Y \& Meier D. 2000. Component and antifungal efficiency of woodVinegar-Liquor Prepared Under Different Carbonization Condition. Wood Research 87: 3436.

Karseno, Darmadji P \& Kapti R. 2001. Daya Hambat Asap Cair Kayu Karet Terhadap Bakteri Pengkontaminan Lateks dan Ribbed Smoke Sheet. Agritech 21(1): 10-15.

Kimura Y, Suto S \& Tatsuka M. 2002. Evaluation of Carcinogenic/Cocarcino genic activity of chikusaku-eki, a bamboo charcoal by-product used as folk remedy in Balab/c 3T3 cells. Biology Pharmaceuticals Bulletin 25(8): 1026-1029.

Lin HC, Murase Y, Shiah TC, Hwang GS, Chen PK \& Wu WL. 2008. Application of Moso Bamboo Vinegar with Different Collection Temperatures to Evaluate Fungi Resistance of Moso Bamboo Materials. J. Fac. Agr. 53(1): 107-113.

Maga JA. 1987. Smoke in Food Processing. CRC Press. Florida: 1-9.

Muis A, Pakki S \& Talanca AH. 2002. Inventarisasi dan identifikasi cendawan yang menyerang biji jagung di Sulawesi Selatan. Pp. 21-30. Hasil Penelitian Hama dan Penyakit. Balitsereal. Maros.

Oramahi HA, Sumardiyono C, Pusposendjojo \& Haryadi. 2006. Identifikasi Jamur Genus Aspergillus pada Gaplek di Kabupaten Gunungkidul. J. Perlindungan Tanaman Indonesia 12(1): 13-24. 
Oramahi HA. 2008. Penyakit Simpanan pada Gaplek yang Disebebkan oleh Aspergillus flavus. Disertasi. Universitas Gadjah Mada. (Tidak dipublikasikan).

Oramahi HA, Diba F \& Wahdina. 2009. Pengendalian Penyakit Pascapanen pada Jagung Berbasis Bahan Alam untuk Mendukung Ketahanan Pangan Nasional. Laporan Penelitian Strategi Nasional Batch I.

Senter SD, Robertson JA \& Meredith FI. 1989. Phenolic Compound of the Mesocarp of Creathaven Peaches during Storage and Ripening. J. Food Sci. 54: 1259-1268.

Sekiyama BL, Ribeiro AB, Machinski PA \& Junior MM. 2005. Aflatoxins, Ochratoxin A and Zearalenone In Maize-Based Food Products. Braz. J. Microbiol. 36: 289-294.

Shiah TC, Wu SK, Huang JC \& Lin HC. 2006. The Fungi Resistance of Bamboo Materials Treated with Bamboo Vinegar Using Soaking Treatment. J. of Agriculture and Forestry NYCU 3(1): 122.
Tranggono, Suhardi, Setiadji B, Darmadji P, Supranto \& Sudarmanto. 1996. Identifikasi Asap Cair dari Berbagai Jenis Kayu dan Tempurung Kelapa. J. Ilmu dan Teknologi Pangan 1(2): 15-24.

Velmurugan N, Han SS \& Lee YS. 2009a. Antifungal Activity of Neutralized Wood Vinegar with Water Extracts of Pinus densiflora and Quercus serrata Saw Dusts. Int. J. Environ. Res. 3(2): 167-176.

Velmurugan N, Chun SS, Han SS \& Lee YS. 2009 b. Characterization of chikusaku-Eki and MokusakuEki and its inhibitory Effect on Sapstaining Fungal Growth in Laboratory Scale. Int. J. Environ. Sci. Tech. 6(1): 13-22.

Yoshimoto T \& Syafii W. 1993. Extractives from some tropical hardwoods and Their Influnces on the Growth of Wood Decaying Fungi. J. Tropical Agriculture 4(2): 31-35.

Widiastuti H \& Panji T. 2007. Pemanfaatan tandan kosong kelapa sawit sisa jamur merang (Volvariella volvacea) (TKSJ) sebagai pupuk organik pada pembibitan kelapa sawit. Menara Perkebunan 75(2): 70-79. 